\section{The effect of kinesiophobia in older people with acute low back pain: longitudinal data from Back Complaints in the Elders (BACE)}

\author{
O efeito da cinesiofobia em idosos com dor \\ lombar aguda: dados longitudinais do estudo \\ Back Complaints in the Elders (BACE)
}

El efecto de la quinesofobia en personas mayores con dolor lumbar agudo: datos longitudinales de Back Complaints in the Elders (BACE)
Diogo Carvalho Felício 1

José Elias Filho 1

Daniele Sirineu Pereira 2

Barbara Zille de Queiroz 2

Amanda Aparecida Oliveira Leopoldino 2

Vitor Tigre Martins Rocha 2

Leani Souza Máximo Pereira 2

doi: $10.1590 / 0102-311 \times 00232920$

\begin{abstract}
This study aimed to investigate the course of low back pain (LBP) intensity over a period of 12 months in older people with and without kinesiophobia.This was an international multicenter study. LBP intensity was examined by using the Numerical Pain Scale at baseline and over five follow-up periods. The Fear-Avoidance Beliefs Questionnaire was used to measure patients' beliefs and fears. The study included 532 older adults (non kinesiophobic = 227; kinesiophobic = 305). The individuals had moderate pain at baseline, with a significant difference observed between the groups. Participants showed a rapid improvement in the first 6 weeks, followed by minor improvements in the succeeding months. However, a significant difference between groups remained during the follow-up period. Independently, kinesiophobia is a significant prognostic factor. These findings suggest the importance of screening for psychosocial factors in the management of older patients with LBP. Practice implications: patients need to be warned that pain can be perpetuated by inappropriate avoidance behaviors that may later lead to disability.
\end{abstract}

Low Back Pain; Aged; Fear

\section{Correspondence}

D. C. Felício

Universidade Federal de Juiz de Fora.

Av. Eugênio do Nascimento s/n, Juiz de Fora, $M G$ 36038-330, Brasil.

diogofelicio@yahoo.com.br

1 Universidade Federal de Juiz de Fora, Juiz de Fora, Brasil.

2 Universidade Federal de Minas Gerais, Belo Horizonte, Brasil. 


\section{Introduction}

Aging is accompanied by an increase in the incidence and prevalence of chronic diseases, and low back pain (LBP) stands out as one of the three main causes of non-fatal health loss for nearly three decades 1 . Historically, LBP research has focused on the general, economically active population. Unfortunately, research about older people is still incipient. A systematic review assessed the agerelated inclusion criteria distribution of participants in randomized controlled trials of LBP interventions. A total of $41.6 \%$ of the included trials excluded people aged $>65$ years 2 . In a systematic review of the course of LBP in older people, only five cohort studies have been found. It was observed that at 3 and 12 months of follow-up, approximately $40 \%$ of participants still reported pain. The authors highlighted the unfavorable prognosis and the need for more evidence on the topic 3 .

Several reasons show why the clinical course of LBP in old adults may be different from younger populations. Older people have a greater number of comorbidities, including sarcopenia. Reports on the relationship between LBP and muscles indicated that LBP is related to lower skeletal muscle mass and intramuscular fat of spinal muscles 4 . The older adults also entail more frequent use of medications 5. Furthermore, the anatomical basis for explaining LBP in older people may be different from young people. The source of LBP 6 in older patients are associated with increases in the probability of symptomatic facet or sacroiliac joint pain and decreases in the probability of intervertebral discs.

The LBP approach is complex. Physical and psychological aspects, including kinesiophobia, must be considered. Kinesiophobia is the term used to define the excessive fear of movement that results in feelings of vulnerability to pain or fear of injury recurrence 7 . Negative beliefs and attitudes can limit the individual's ability to deal with symptoms and reduce their ability to adopt positive coping strategies 8 .

Studies regarding kinesiophobia and pain have provided controversial results. In a prospective cohort study, Ranger et al. 9 investigated the relationship between kinesiophobia, catastrophization, depression, and anxiety with LBP intensity and disability. When all factors were added to the regression model, only catastrophization and depression were statistically associated with the worst outcomes 9 . On the other hand, Nordstoga et al. 10 observed an association between kinesiophobia and pain in another prospective cohort study of individuals with LBP 10. Note that, the aforementioned studies did not include an older population. Kinesiophobia increases the patients' chance of developing symptoms of depression and disability when compared to those who had positive beliefs and attitudes 11. Thus, considering the lack of studies on LBP in older people and the possible relationship between psychosocial factors, this study aimed to investigate the course of LBP intensity over a 12 month-period in older people with and without kinesiophobia.

\section{Materials and methods}

\section{Study design}

This was an observational, longitudinal, ancillary study of the Back Complaints in the Elders study (BACE), an international multicenter study 12. The Federal University of Minas Gerais's Ethics Research Committee approved this study (ETIC 0100.0.203.00-11) and all participants were informed of the study details and signed an informed consent form before participating in this study.

\section{Participants}

Sample selection was conducted by convenience. The inclusion criteria were individuals (aged $\geq 60$ years) who presented a new (acute) episode of LBP (with current symptoms that had been occurring for $<6$ weeks). The episode was defined as new if the person did not seek for care because of LBP during the 6 months before data collection. LBP was defined as any pain between the lowest ribs and the inferior gluteal folds, with or without leg pain 12. Participants with severe diseases (infectious processes, malignant tumors, cauda equina syndrome), cognitive impairment 13 , severe visual, motor, or hearing loss were excluded from the study. 


\section{Procedures}

Data on sample characteristics, sociodemographic, and clinical conditions of the older adults, such as age, education level, number of comorbidities, body mass index (BMI), depressive symptoms 14, and sex were obtained using a standardized multidimensional questionnaire defined by the BACE research group. All questionnaires were applied by trained researchers.

\section{Pain}

LBP intensity was assessed with the Numerical Pain Scale (NPS). A reading of 0 (zero) indicated no pain, whereas 10 indicated the worst pain possible (severe pain). LBP can be classified as none (for 0 score), mild (1, 2, or 3), moderate (4, 5, or 6), and severe $(7,8,9$, or 10) 15 . LBP intensity was assessed at baseline and over five follow-up periods (6 weeks, 3, 6, 9, and 12 months). This is a simple instrument that is easy to apply and has high reliability and reproducibility 16.

\section{Kinesiophobia}

The Fear-Avoidance Beliefs Questionnaire (FABQ) was used to measure patients' beliefs and fears. The FABQ is composed of 16 self-reported items. Items are divided into two subscales, FABQ-Phys and FABQ-Work. The FABQ two subscales present a score that can range from 0 to 6 . Based on the sample, participants completed only the FABQ-Phys. Within the FABQ-Phys, 4 out of the 5 questions are scored, for a maximal score of 24 points. Higher FABQ scores indicate a greater tendency to demonstrate avoidance of activity ${ }^{7}$. Psychometric properties of the FABQ were validated by Abreu et al. 17 and had an intra-class correlation coefficient between 0.8 and 0.9 17. Participants were divided into older people with (kin, FABQ-Phys $\geq 16$ ) and without (nKin, FABQ-Phys $\leq 15$ ) kinesiophobia 18. An assessment to differentiate the groups was fulfilled at the baseline.

\section{Statistical analysis}

Sample characterization was determined using descriptive statistics. Data distribution was determined using the Shapiro Wilk's test. To verify if there were differences between the groups, Student's paired t-test or chi squared test were performed at baseline. In order to examine the clinical course of LBP, the Generalized Estimating Equation (GEE) model was used. The Tweedie model was employed according to the Quasi-likelihood under Independence Model Criterion (QIC). The FABQ-Phys score and time were the independent variables, while the intensity of the LBP was the dependent variable. For comparison between means, the pairwise contrast with Bonferroni correction method was used. A significance level of 0.05 was considered statistically significant. Statistical analysis was performed using SPSS (https://www.ibm.com/).

\section{Results}

The research team screened 3,711 older adults to participate in the BACE study. Among them, 532 participants met the inclusion criteria (Figure 1). Missing values corresponded to $24.6 \%$ of the data.

Table 1 shows the sociodemographic and clinical characteristics of the older adults, divided into the nKin and Kin groups. The data are presented as the mean \pm standard deviation (SD) or percentage (\%). Generally, most participants were female patients (nKin group = 84.1\%; Kin group = 86.8\%), with medium educational level ( $\mathrm{nKin}$ group $=11.6 \pm 2.6$ years; Kin group $=13.9 \pm 3.1$ years), multiple comorbidities (nKin group $=4.9 \pm 2.6$; Kin group $=4.8 \pm 2.7$ ), obesity (nKin group $=29.4 \pm 5.0 \mathrm{~kg} / \mathrm{m}^{2}$; Kin group $\left.=28.6 \pm 5.2 \mathrm{~kg} / \mathrm{m}^{2}\right)$, and depressive symptoms $(\mathrm{nKin}$ group $=22.3 \pm 10.3$; Kin group $=21.2 \pm 9.8$ ) 


\section{Figure 1}

Flowchart of patient recruitment. Belo Horizonte, Minas Gerais State, Brazil, from September 2011 to December 2013.

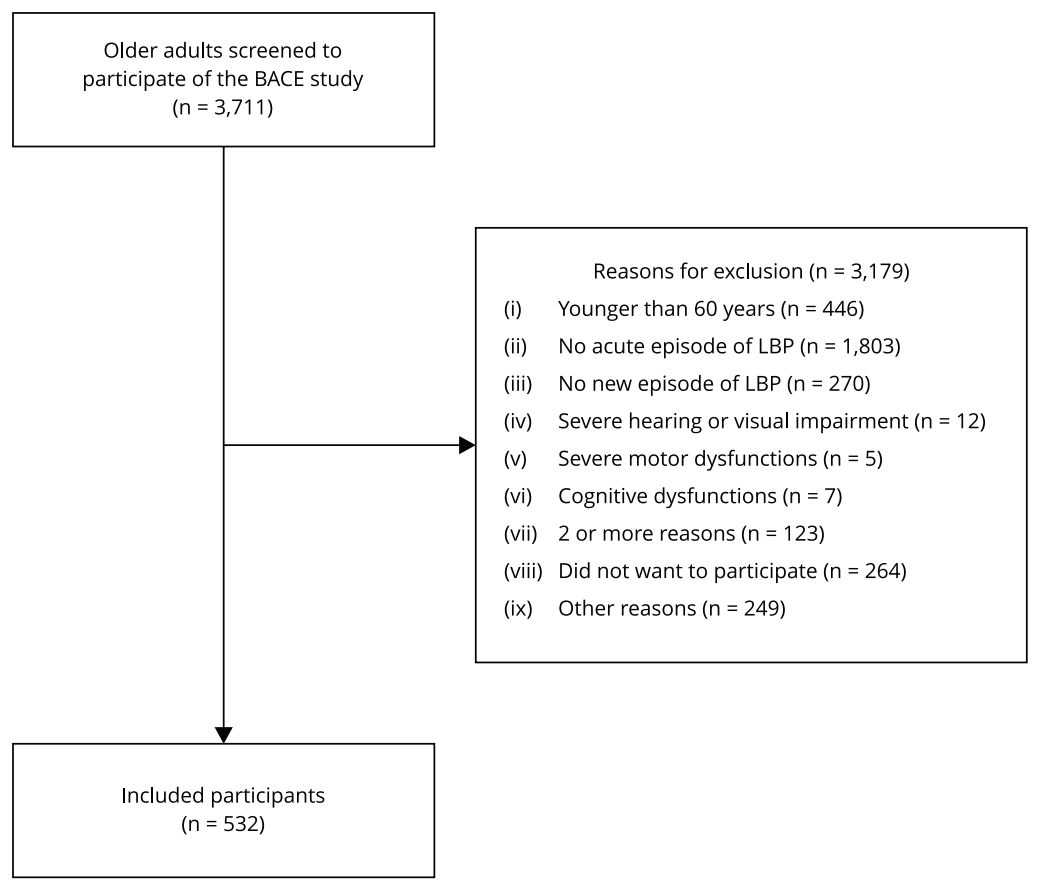

BACE: Back Complaints in the Elders study; LBP: low back pain.

Table 1

Baseline characteristics of the study participants $(n=532)$. Belo Horizonte, Minas Gerais State, Brazil, from September 2011 to December 2013.

\begin{tabular}{|c|c|c|c|}
\hline Characteristic & $\begin{array}{l}\text { Non kinesiophobic } \\
\qquad(n=227)\end{array}$ & $\begin{array}{l}\text { Kinesiophobic } \\
\quad(n=305)\end{array}$ & p-value \\
\hline Age (years) [mean $\pm S D]$ & $68.7 \pm 6.0$ & $69.2 \pm 6.4$ & $0.86 *$ \\
\hline Education (years) $[$ mean $\pm S D]$ & $11.6 \pm 2.6$ & $13.9 \pm 3.1$ & $0.57 *$ \\
\hline Comorbidities (n) [mean $\pm S D]$ & $4.9 \pm 2.6$ & $4.8 \pm 2.7$ & $0.40 *$ \\
\hline Body Mass Index $\left(\mathrm{kg} / \mathrm{m}^{2}\right)[$ mean $\pm \mathrm{SD}]$ & $29.4 \pm 5.0$ & $28.6 \pm 5.2$ & 0.84 * \\
\hline Center for Epidemiological Studies Depression (0-60) [mean \pm SD] & $22.3 \pm 10.3$ & $21.2 \pm 9.8$ & $0.29 *$ \\
\hline Pain (0-10) [mean $\pm S D]$ & $4.4 \pm 3.0$ & $5.0 \pm 3.1$ & $0.03 *, \star \star$ \\
\hline Fear-Avoidance Beliefs Questionnaire (0-24) & $9.8 \pm 2.2$ & $20.2 \pm 4.6$ & $<0.01 *, * *$ \\
\hline Women [\%] & 84.1 & 86.8 & $0.37 * \star *$ \\
\hline
\end{tabular}

SD: standard deviation.

* Independent t-test;

** Significant statistical difference;

*** Chi-square test. 
Figure 2 shows the intensity of LBP assessed by Numerical Pain Scale (0-10) at baseline and over five follow-up periods (6 weeks, 3, 6, 9, and 12 months). It was observed that the group of non Kinesiophobic older adults (FABQ-Phys $\leq 15$ ) had a better clinical course of LBP.

Table 2 shows the comparison of the baseline with the five follow-up periods. The pairwise contrast showed statistically significant results between the groups throughout the study period.

\section{Figure 2}

Clinical course of low back pain. Belo Horizonte, Minas Gerais State, Brazil, from September 2011 to December 2013.

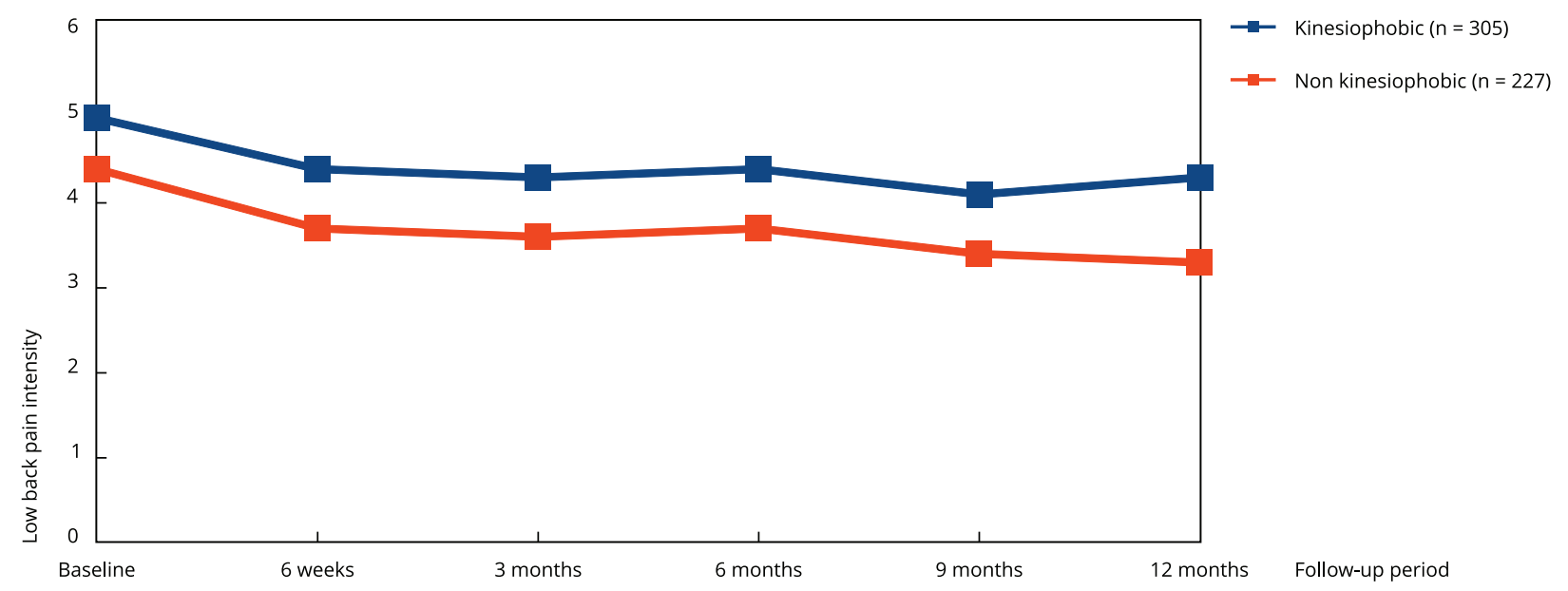

Table 2

comparison of the baseline low back pain intensity in kinesiophobic $(n=305)$ and non kinesiophobic older adults $(n=227)$ with the 5 follow-up periods. Belo Horizonte, Minas Gerais State, Brazil, from September 2011 to December 2013.

\begin{tabular}{|c|c|c|c|c|}
\hline Period & Mean difference & Standard error & Bonferroni Sig & $95 \% \mathrm{Cl}$ \\
\hline \multicolumn{5}{|l|}{ Baseline } \\
\hline 6 weeks & 0.65 & 0.17 & $<0.01 *$ & $0.12-1.12$ \\
\hline 3 months & 0.75 & 0.18 & $<0.01$ * & $0.19-1.27$ \\
\hline 6 months & 0.65 & 0.19 & $<0.01 *$ & $0.07-1.21$ \\
\hline 9 months & 0.95 & 0.20 & $<0.01 *$ & $0.34-1.52$ \\
\hline 12 months & 0.90 & 0.19 & $<0.01 *$ & $0.22-1.38$ \\
\hline
\end{tabular}

95\% Cl: 95\% confidence interval.

* Different from the baseline. 


\section{Discussion}

This study aimed to compare the course of LBP intensity in older adults with and without kinesiophobia for 12 months. It was observed that kinesiophobic older individuals presented greater pain complaints during the 12 -month period.

The groups were comprised of a majority of female patients. The literature indicates differences between genders regarding the incidence and clinical course of LBP which are higher in women 19. Possible explanations are abdominal muscle strength 20 , hormonal aspects 21 , workplace 22 , and negative beliefs 23 . The older adults had low education level, suggesting that older people with higher education have higher income, are more engaged in social participation, physical activity, leisure activities, and prevention and treatment of this disease 24. Participants had a large number of comorbidities and the presence and severity of comorbidities are independently associated with worst prognosis of LBP 25. Regarding BMI, the older adults were mostly obese. Body fat releases inflammatory mediators that are catabolic to muscle fibers. Older individuals with LBP have the highest sTNF plasma levels and the worst functional performance 26 . Finally, some older adults presented depressive symptoms. Depression can trigger the onset of back pain or worsen it. A longitudinal study showed that older people with depressive symptom score at baseline were twice as likely to have LBP at the 4-year follow-up 27.

To the best of our knowledge, this is the first study to investigate the association between kinesiophobia and the clinical course of acute LBP in older adults using the FABQ. Aasdahl et al. 28 in a cohort study stated that FABQ is not a good measure of fear-avoidance beliefs about physical activity, and the predictive property of the FABQ is most likely related to expectations rather than fear 28 . On the other hand, our findings show that kinesiophobia evaluated with the FABQ is a significant prognostic factor and we recommend using the instrument to measure fear-avoidance beliefs in acute conditions. Basler et al. 29 investigated the validity of FABQ in older individuals. They divided the participants into groups with LBP $(\mathrm{n}=103,71.4 \pm 5.2$ years) and without pain complaints $(\mathrm{n}=59,71.1 \pm 4.7$ years). The results were consistent with those described for the younger adult population. Thus, the instrument was validated for use in the older population 29.

The older adults had moderate pain at baseline, with a significant difference observed between groups. They showed a rapid improvement in the first six weeks, followed by minor improvements in the succeeding months. This pattern is similar to the course of LBP with other populations 30 . However, a significant difference between groups remained during the follow-up period.

The group of non-kinesiophobic patients had a pain score reduction of 1.3 points, which is within the range of the minimal clinically significant differences for patients with acute pain according to data published in a meta-analysis (0.4-4 on a scale of 10) 31 . This aspect highlights how psychological factors affect pain experience. The kinesiophobia model proposes that negative beliefs culminate in catastrophic responses. If the patients interpret the pain stimulus as threatening, they became hypervigilant in pain monitoring, worsening the results 32 .

Some authors discuss changes in the brain tissue as a result of continued pain stimulation in patients with LBP 33 . In a study of patients with LBP, it was identified a $1.3 \mathrm{~cm}^{3}$ reduction in gray matter density for each year that a patient experienced pain ${ }^{34}$. In a survey of 29 participants with LBP, it was concluded that the change in the gray matter was associated with the catastrophization and low tolerance to pain 35 . Atrophy of the gray matter was also related to the transition from acute to chronic pain 36 . A study by Larson et al. 37 with 433 older adults showed an association between chronic pain and high levels of kinesiophobia. The authors concluded that possible interventions to kinesiophobia in the older adults should aim to reduce the pain intensity and strengthen health beliefs 37 .

Patients need to be informed that pain can be perpetuated by negative beliefs that may lead to disability. Sions et al. 38 examined the association between FABQ-Phys, disability (Oswestry Disability Questionnaire, Quebec Back Pain Disability Scale), and the summary of the physical component of the Medical Outcomes Study 36-Item Short Form Survey in older adults with LBP $(\mathrm{n}=107,79.7 \pm 5.7$ years). The authors found that the FABQ-Phys score independently explained 3-6\% of the functionality results. In a survey of patients with chronic LBP $(n=55$, mean age $46.4 \pm 14.8$ years $) 38$. Chung et al. 39 found a significant correlation between the FABQ-Phys and Roland Morris Questionnaire $(r=0.32)$ and the Oswestry Disability Questionnaire $(\mathrm{r}=0.19)$ 39. In a recent publication by our research group, the 
authors identified that worsened kinesiophobia, poor physical and mental health, stiffness of the lumbar spine, low self-efficacy during falls, difficulty in sleeping, higher BMI, greater pain intensity, sex, and worse functional mobility were significantly associated with disability 40 . The aforementioned studies reinforce that distorted thoughts play a central role in determining adverse health outcomes.

Individuals with kinesiophobia have an excessive, irrational, and debilitating fear of movement that results in feelings of vulnerability to pain and an addictive cycle of disuse, deconditioning, disability, and depression ${ }^{41}$. Our findings reinforce the need to examine psychosocial factors in patients with acute LBP.

We highlight the limitation of external validity since females compose the majority of the sample. Besides, LBP is self-reported, but this type of assessment is common due to the subjectivity of LBP and it is well accepted in epidemiological studies. Another limitation in this study is missing values. However, we also emphasize the study use of the GEE model which allowed the correction of individuals' observations over time and accommodated unbalanced data from the missing data 42 . Lastly, the treatment received during the course of the study was not standardized. After the inclusion procedure, the patients were free to contact other health professionals. Among the strengths of the study are the adequate sample size, the homogeneity of groups, and the extensive 12-month follow-up period.

\section{Conclusion}

Kinesiophobic older adults have a worse clinical course of acute LBP. Independently, kinesiophobia is a significant prognostic factor. These findings suggest the importance of screening for psychosocial factors in the management of older patients with pain complaints.

\section{Contributors}

D. C. Felício contributed in the conceptualization of the study, data curation, formal analysis, methodology, writing-original draft, writing-review and editing the text. J. Elias Filho contributed in the formal analysis of the study, methodology, writingoriginal draft, writing-review and editing the text. D. S. Pereira contributed in the conceptualization of the study, data curation, formal analysis, and writing-original draft. B. Z. Queiroz contributed in the data curation, formal analysis, and writing-original draft. A. A. O. Leopoldino and V. T. M. Rocha contributed in the conceptualization, data curation, formal analysis, methodology writing-review and editing the text. L. S. M. Pereira contributed in the conceptualization of the study, formal analysis, methodology, writing-original draft, writingreview, and editing the text. All authors approved the final version of the text for publication.

\section{Additional informations}

ORCID: Diogo Carvalho Felício (0000-0001-51381884); José Elias Filho (0000-0002-4251-0290); Daniele Sirineu Pereira (0000-0002-4868-9244); Barbara Zille de Queiroz (0000-0003-1014-1512); Amanda Aparecida Oliveira Leopoldino (00000002-3958-7107); Vitor Tigre Martins Rocha (0000-0002-5789-0820); Leani Souza Máximo Pereira (0000-0001-7253-4392).

\section{Acknowledgments}

This study was financed by the Brazilian National Research Council (CNPq, process 150262/2019-1) and by the Brazilian Graduate Studies Coordinating Board (CAPES, finance code 001). 


\section{References}

1. GBD 2017 Disease and Injury Incidence and Prevalence Collaborators. Global, regional, and national incidence, prevalence, and years lived with disability for 354 diseases and injuries for 195 countries and territories, 19902017: a systematic analysis for the Global Burden. Lancet 2018; 392:1789-858.

2. Paeck T, Ferreira ML, Sun C, Lin C-WC, Tiedemann A, Maher CG. Are older adults missing from low back pain clinical trials? A systematic review and meta-analysis. Arthritis Care Res (Hoboken) 2015; 66:1220-6.

3. Scheele J, Luijsterburg PAJ, Bierma-zeinstra SMA, Koes BW. Course of back complaints in older adults: a systematic literature review. Eur J Phys Rehabil Med 2012; 48:379-86.

4. Sakai Y, Matsui H, Ito S, Hida T, Ito K, Koshimizu H, et al. Sarcopenia in older patients with chronic low back pain. Osteoporos Sarcopenia 2017; 3:195-200.

5. Leopoldino AAO, Megale RZ, Diz JBM, Moreira BS, Lustosa LP, Pereira LSM, et al. Influence of the number and severity of comorbidities in the course of acute non-specific low back pain in older adults: longitudinal results from the Back Complaints in the Elders (BACO-Brazil). Age Ageing 2019; 49:96-101.

6. Depalma MJ, Ketchum JM, Saullo T. What is the source of chronic low back pain and does age play a role? Pain Med 2011; 12:224-33.

7. Waddell G, Newton M, Henderson I, Somerville D, Main CJ. A Fear-Avoidance Beliefs Questionnaire (FABQ) and the role of fearavoidance beliefs in chronic low back pain and disability. Pain 1993; 52:157-68.

8. Alaca N, Kaba H, Atalay A. Associations between the severity of disability level and fear of movement and pain beliefs in patients with chronic low back pain. J Back Musculoskelet Rehabil 2020; 33:785-91.

9. Ranger TA, Cicuttini FM, Jensen TS, Manniche C, Heritier S, Urquhart DM. Catastrophization, fear of movement, anxiety, and depression are associated with persistent, severe low back pain, and disability. Spine J 2020; 20:857-65.

10. Nordstoga AL, Meisingset I, Vasseljen O, Nilsen TIL, Unsgaard-Tondel M. Longitudinal associations of kinematics and fear-avoidance beliefs with disability, work ability and pain intensity in persons with low back pain. Musculoskelet Sci Pract 2019; 41:49-54.

11. Grotle M, Vøllestad NK, Brox JI. Clinical course and impact of fear-avoidance beliefs in low back pain: prospective cohort study of acute and chronic low back pain: II. Spine (Phila Pa 1976) 2006; 31:1038-46.

12. Scheele S, Luijsterburg PAJ, Ferreira ML, Maher CG, Pereira L, Peul WC, et al. Back Complaints in the Elders (BACO); design of cohort studies in primary care: an international consortium. BMC Musculoskelet Disord 2011; 12:193-202
13. Bertolucci PHF, Brucki SMD, Campacci SR, Juliano Y. O mini-exame do estado mental em uma população geral. Arq Neuropsiquiatr 1994;52:1-7

14. Batistoni SS, Neri AL, Cupertino AP. Validity of the Center for Epidemiological Studies Depression Scale among Brazilian older. Rev Saúde Pública 2007; 41:598-605.

15. Williamson A, Hoggart B. Pain: a review of three commonly used pain rating scales. J Clin Nurs 2005; 4:798-804.

16. Childs JD, Piva SR, Fritz JM. Responsiveness of the Numeric Pain Rating Scale in patients with low back pain. Spine 2005; 30:1331-4.

17. Abreu AM, Faria CDCM, Cardoso SMV, Teixeira-Salmela LF. Versão brasileira do Fear Avoidance Beliefs Questionnaire. Cad Saúde Pública 2008; 24:615-23.

18. Williamson E. Fear Avoidance Behavior Questionnaire. Aust J Physiother 2006; 52:149.

19. Ochsmann E, Rüger H, Kraus T, Drexler H, Letzel S, Münster E. Gender-specific risk factors for acute low back pain: starting points for target-group-specific prevention. Schmerz 2009; 23:377-84.

20. Kato S, Murakami H, Demura S, Yoshioka K, Shinmura K, Yokogawa N, et al. Abdominal trunk muscle weakness and its association with chronic low back pain and risk of falling in older women. BMC Musculoskelet Disord 2019; 20:273

21. Song XX, Shi S, Guo Z, Li XF, Yu BW. Estrogen receptors involvement in intervertebral discogenic pain of the older women: colocalization and correlation with the expression of Substance P in nucleus pulposus. Oncotarget 2017; 8:38136-44.

22. Yang H, Haldeman S, Lu ML, Baker D. Low back pain prevalence and related workplace psychosocial risk factors: a study using data from the 2010 National Health Interview Survey. J Manipulative Physiol Ther 2016; 39:459-72.

23. Alyousef B, Cicuttini FM, Davis SR, Bell R, Botlero R, Urquhart DM. Negative beliefs about back pain are associated with persistent, high levels of low back disability in communitybased women. Menopause 2018; 25:977-984.

24. Nurrika D, Zhang S, Tomata Y, Sugawara Y, Tanji F, Tsuji I. Education level and incident functional disability in older Japanese: the Ohsaki Cohort 2006 study. PLoS One 2019; 14:e021338614.

25. Leopoldino AAO, Megale RZ, Diz JBM, Moreira BS, Lustosa LP, Pereira LSM, et al. Influence of the number and severity of comorbidities in the course of acute non-specific low back pain in older adults: longitudinal results from the Back Complaints in the Elders (BACO-Brazil). Age Ageing 2019; 49:96-101. 
26. Queiroz AZ, Pereira DS, Rosa NMB, Lopes RA, Felício DC, Pereira DG, et al. Functional performance and plasma cytokine levels in older women with and without low back pain. J Back Musculoskelet Rehabil 2015; 28:343-9.

27. Docking RE, Fleming J, Brayne C, Zhao J, Macfarlane GJ, Jones GT, et al. Epidemiology of back pain in older adults: prevalence and risk factors for back pain onset. Rheumatol 2011; 50:1645-53.

28. Aasdahl L, Marchand GH, Gismervik SØ, Myhre K, Fimland MS, Røe C. The Fear Avoidance Beliefs Questionnaire (FABQ) does it really measure fear beliefs? Spine (Phila Pa 1976) 2020; 45:134-40.

29. Basler HD, Luckmann J, Wolf U, Quint S. Fearavoidance beliefs, physical activity, and disability in older individuals with chronic low back pain and healthy controls. Clin J Pain 2008; 24:604-10.

30. Artus M, Windt DVD, Jordan KP, Croft PR. The clinical course of low back pain: a metaanalysis comparing outcomes in randomised clinical trials (RCTs) and observational studies. BMC Musculoskelet Disord 2014; 15:68.

31. Olsen MF, Bjerre E, Hansen MD, Hilden J, Landler NE, Tendal B, et al. Pain relief that matters to patients: systematic review of empirical studies assessing the minimum clinically important difference in acute pain. BMC Med 2017; 15:35.

32. Wertli MM, Rasmussen-Barr E, Held U, Weiser S, Bachmann LM, Brunner F. Fear-avoidance beliefs-a moderator of treatment efficacy in patients with low back pain: a systematic review. Spine J 2014; 14:2658-78.

33. Fritz HC, McAuley JH, Wittfeld K, Hegenscheid K, Schmidt CO, Langner S, et al. Chronic back pain is associated with decreased prefrontal and anterior insular gray matter: results from a Population-Based Cohort Study. J Pain 2016; 17:111-8.

34. Apkarian AV, Sosa Y, Sonty S, Levy RM, Harden RN, Parrish TB, et al. Chronic back pain is associated with decreased prefrontal and thalamic gray matter density. J Neurosci 2004; 24:10410-5.
35. Chehadi O, Suchan B, Konietzny K, Köster O, Schmidt-Wilcke T, Hasenbring MI. Gray matter alteration associated with pain catastrophizing in patients 6 months after lumbar disk surgery: a voxel-based morphometry study. Pain Rep 2017; 2:e617.

36. Yuan C, Shi H, Pan P, Dai Z, Zhong J, Ma H, et al. Gray matter abnormalities associated with chronic back pain: a meta-analysis of voxelbased morphometric studies. Clin J Pain 2017; 33:983-90.

37. Larsson C, Ekvall Hansson E, Sundquist K, Jakobsson U. Kinesiophobia and its relation to pain characteristics and cognitive affective variables in older adults with chronic pain. BMC Geriatr 2016; 16:128.

38. Sions JM, Hicks GE. Fear-avoidance beliefs are associated with disability in older American adults with low back pain. Phys Ther 2011; 91:525-34.

39. Chung EJ, Hur Y, Lee B. A study of the relationship among fear-avoidance beliefs, pain and disability index in patients with low back pain. J Exerc Rehabil 2013; 9:32-5.

40. Silva JP, Jesus-Moraleida F, Felício DC, Queiroz BZ, Ferreira ML, Pereira LSM. Fatores biopsicossociais associados com a incapacidade em idosos com dor lombar aguda: estudo BACE-Brasil. Ciênc Saúde Colet 2019; 24:2679-90.

41. Leeuw M, Goossens ME, Linton SJ, Crombez G, Boersma K, Vlaeyen JWS. The fear-avoidance model of musculoskeletal pain: current state of scientific evidence. J Behav Med 2007; 30:77-94.

42. Cnaan A, Laird NM, Slasor P. Using the general linear mixed model to analyse unbalanced repeated measures and longitudinal data. Stat Med 1997; 16:2349-80. 


\section{Resumo}

O estudo teve como objetivo investigar a evolução da intensidade da dor lombar (DL) ao longo de 12 meses em idosos com e sem cinesiofobia. Este foi um estudo multicêntrico internacional. A intensidade da DL foi avaliada com a Numerical Pain Scale na linha de base e ao longo de 5 períodos de seguimento. As crenças e os medos dos pacientes foram medidos com o Fear-Avoidance Beliefs Questionnaire. O estudo incluiu 532 idosos ( $\mathrm{sem}$ cinesiofobia $=227$; com cinesiofobia $=305)$. Os idosos apresentavam dor moderada na linha de base, com uma diferença significativa entre os grupos. Os participantes mostraram melhora rápida nas primeiras seis semanas, seguida por melhoras menores nos meses seguintes. Entretanto, persistiu uma diferença significativa entre os grupos durante o periodo de seguimento. A cinesiofobia é um fator prognóstico importante e independente. Os achados sugerem a importância da triagem de fatores psicossociais no manejo de pacientes idosos com DL. Implicações práticas: os pacientes devem ser advertidos que a dor pode ser perpetuada por comportamentos inadequados de evitação, podendo à incapacidade no longo prazo.

Dor Lombar; Idoso; Medo

\section{Resumen}

El objetivo fue investigar el curso de la intensidad del dolor lumbar (LBP), durante un período de 12 meses, en personas ancianas con y sin quinesofobia. Se trata de un estudio multicéntrico internacional. La intensidad del LBP se evaluó usando la Escala Numérica de Dolor en una base de referencia y sobre 5 periodos de seguimiento. Con el fin de medir las creencias y temores de los pacientes, usamos el Fear-Avoidance Beliefs Questionnaire. El estudio incluyó a 532 ancianos (no quinesofóbicos = 227; quinesofóbicos $=305$ ). Los ancianos sufrieron un dolor moderado en la base de referencia, con una significativa diferencia observada entre grupos. Los participantes mostraron una rápida mejora durante las 6 primeras semanas, seguidas por mejoras menores en los meses siguientes. No obstante, se mantuvo una diferencia significativa entre grupos durante el período de seguimiento. Independientemente, la quinesofobia es un factor pronóstico importante. Estos resultados sugieren la importancia de monitorear factores psicosociales en la gestión de pacientes ancianos con LBP. Implicaciones clinicas: los pacientes necesitan ser avisados de que el dolor puede perpetuarse por comportamientos inapropiados de prevención que quizás más tarde conduzcan a la discapacidad.

Dolor de la Región Lumbar; Anciano; Miedo
Submitted on 05/Aug/2020

Final version resubmitted on 19/Jan/2021

Approved on 04/Mar/2021 